\title{
Do Managers In Chinese Family Firms Learn From The Market? Evidence From Chinese Private Placement
}

Wanli Li, Xi'an Jiaotong University \& Shanghai University of International Business and Economics, China Weiwei Gao, Xi'an Jiaotong University, China

Wei Sun, Xi'an Jiaotong University, China

\begin{abstract}
Recent empirical papers report managers' learning in merger and acquisition (M\&A) decisions and family control is central in many countries. Does learning exist in family firms' financing decisions? Based on the announced private placements from Chinese family firms, we investigate the relation between managers' final decisions in family firms and the market reaction to the announcement. Our analysis suggests that a non-linear relation exists between managers' learning and family control. Managers generally learn from the market when making final decisions but family involvement can reduce this probability. Supplementary testing indicates that managers in family firms with low ownership are less likely to learn from the market than those in family firms with high ownership. Further analysis suggests that corporate governance can influence managers' learning. Family member' participation in purchasing the placed shares and serve as the top managers can make manager' learning less likely when the ownership is low. Independent directors in family firms don't play their due role in supervising the behavior of managers and large shareholders.
\end{abstract}

Keywords: Chinese Family Firm; Private Placement; Learning; Corporate Governance

\section{INTRODUCTION}

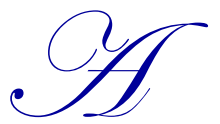

large fraction of business is organized as family control in most countries around the world (La Porta, Lopez-de-Silanes, and Shleifer, 1999; Claessens, Djankov, and Lang, 2000; Burkart, Panunzi, and Shleifer, 2003). In continental Europe, most of the publicly-held firms are familycontrolled (Faccio and Lang, 2002), and in the US, families are present in one-third of the S\&P 500 firms (Anderson and Reeb, 2003). In China, benefiting from the government's policy promoting the development of private enterprises, family firms have developed to a new stage, and more and more are getting publicly traded. Despite the large amount of equity the families hold, the empirical evidences on family members' behavior are converse.

The core of the debate is whether the family firms act as an efficient organization or they are an outcome of cultural norms which may harm the firm value and corporate decisions (Bertrand and Schoar, 2006). On one hand, family ownership can mitigate the conflict of interests between shareholders and managers, which is called Type I agency problem (Jensen and Meckling, 1976). Some evidences show that family firms outperform non-family firms in market valuation and profitability (Anderson and Reeb, 2003; Maury, 2006; Villalonga and Amit, 2006; Andres, 2008). Firm value is maximized for the shareholders, including both the family and non-family shareholders. And in accordance with the stewardship theory, the families, who are expected to monitor the managers, are less likely to manage earnings (Wang, 2006; Ali, Chen, and Radhakrishnan, 2007), for their interests are more closely aligned with the firms'. On the other hand, the involvement of family in business can give rise to the conflict of interests between the controlling and non-controlling shareholders, which is called Type II agency problems (Morck and Yeung, 2003). Controlling the business, the family may harm the non-family shareholders' interest (Burkart, 
Panunzi, and Shleifer, 2003), especially in emerging markets where investor protection is weak and information transparency is low (Faccio, Lang, and Young, 2001; Bertrand, Mehta, and Mullainathan, 2002).

Whether the involvement of families in business is more or less valuable than non-family firms still remains a question. In this paper, based on the condition that Chinese family firms present a much higher ownership concentration and higher degrees of separation between cash-flow rights and voting rights (Cheng, 2014), we take a different approach to address this question using the sample of private placements announced by family firms from China.

In 2006, with the issue of the Administrative Measures for the Issuance of Securities by Listed Companies by the CSRC (China Securities Regulatory Commission), private placement was first regulated and recognized as one way of refinancing in China. Since then, private placement has been more and more popular due to its low requirement ${ }^{1}$. Therefore, many small-to-medium size enterprises have been attracted by this kind of convenience to refinance through private placement in China in recent years, which makes up the difficulties in acquiring bank loans (Berger and Udell, 2002; Chakraborty and Hu, 2006; Uchida, Udell, and Yamori, 2012).

Table 1: The Implement Of Private Placement From 2006 To 2013

\begin{tabular}{lcccccccccc}
\hline \multicolumn{1}{c}{ Firm Type } & Final State & $\mathbf{2 0 0 6}$ & $\mathbf{2 0 0 7}$ & $\mathbf{2 0 0 8}$ & $\mathbf{2 0 0 9}$ & $\mathbf{2 0 1 0}$ & $\mathbf{2 0 1 1}$ & $\mathbf{2 0 1 2}$ & $\mathbf{2 0 1 3}$ & Total \\
\hline \multirow{4}{*}{ Family firms } & Completed & 39 & 37 & 20 & 58 & 77 & 58 & 100 & 90 & 479 \\
& Cancelled & 17 & 32 & 39 & 28 & 26 & 35 & 48 & 53 & 278 \\
& Total & 56 & 69 & 59 & 86 & 103 & 93 & 148 & 143 & 757 \\
\hline \multirow{2}{*}{ Non-family } & Completed & 76 & 74 & 47 & 87 & 92 & 67 & 139 & 80 & 662 \\
firms & Cancelled & 31 & 47 & 45 & 29 & 25 & 40 & 37 & 30 & 284 \\
& Total & 107 & 121 & 92 & 116 & 117 & 107 & 176 & 110 & 946 \\
\hline
\end{tabular}

As illustrated in Table 1 and Figure 1, the number of private placement began to increase in $2006 .{ }^{2}$ By the end of 2012, listed companies from Chinese A-share market have announced 1703 private placements in total, among which family firms account for nearly 45\%. However, the proportion of the cancel of previous announcement from both the family and non-family firms are very high. And on average, the cancel from the family firms is higher than non-family firms. Since family firms prefer private to public equity financing with the intention to maintain family control ( $\mathrm{Wu}$, Chua, and Chrisman, 2007), what causes family firms not to implement the announced plans? Does the involvement of family in business affect the final implementation?
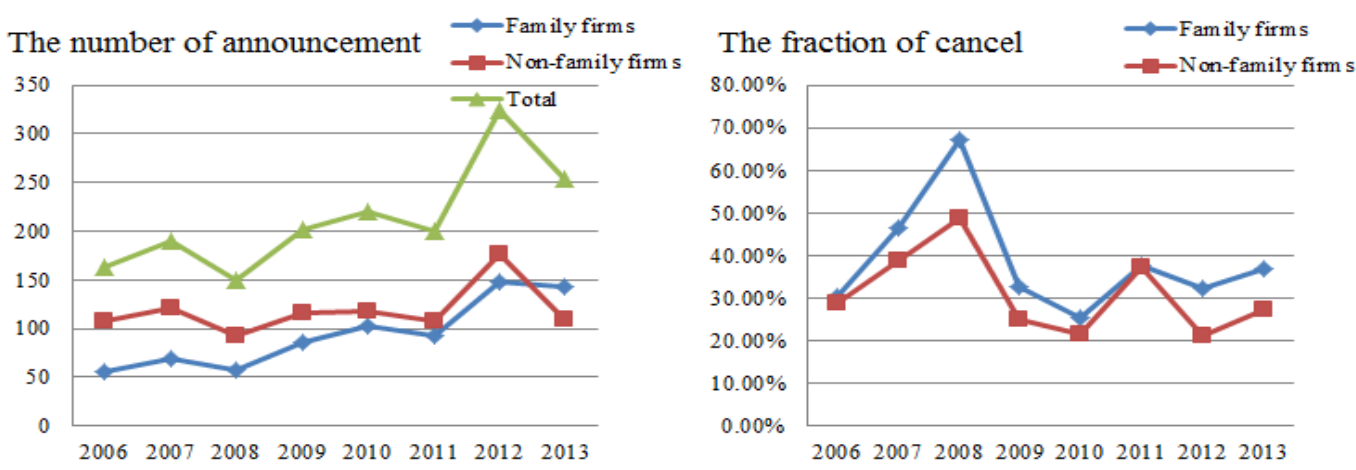

Figure 1: The Implement Of Private Placement From 2006 To 2013

\footnotetext{
${ }^{1}$ Administrative Measures for the Issuance of Securities by Listed Companies, regulates that the number of the purchasers can't be more than 10 , that the issue price can't be lower than $90 \%$ of the average price for the 20 trading days prior to the pricing benchmark day, that the shares issued can't be transferred within 12 months and the shares purchased by large stockholders can't be transferred within 36 months, that the use of the raising funds complies with the state industrial policies. Apart from these regulations, there are no other special restrictions on company's profitability and size.

${ }^{2}$ There is a sharp down in 2008 and 2013. Because financial crisis swept the world in 2008 and financing was unavoidably under the influence. The sample excludes the announcements with unknown final state and some announcements in 2013 are still in their validity period hitherto.
} 
The heart of the efficient market hypothesis (EMH) is that the capital market has a strong ability in dealing with public information, which is superior to any individuals or institutions. The announcement has not been admitted, the capital market will feedback to the company by trading down its stock price. "Learning" means that managers will extract useful information from the market feedback and impound it into the final decisions (Luo, 2005). In other words, apart from redistributing wealth among traders in the secondary market by trading stocks, the capital market can also generate information that guides managers' decisions. So is the feedback from the market the main cause why family firms not implement the announced plans which is listed in Table 1? That is, do managers in family firms learn from the market during private placement? Are there systematic differences between family and non-family firms? And is private placement a tool utilized by the families to realize their private benefits, which is consistent with the previous studies (Barclay, Holderness, and Sheehan, 2007)?

Focusing on the relation between managers' final decisions and the market reaction to the announcement, we analyze the announced private placement from Chinese A-share market from the year 2006 to 2013 and the influence of family firms' characteristics on the relation. The findings, which are important in light of previous literature, fit into several research areas and expand the research perspective. First, we provide a more comprehensive measurement, which accords with the situations in China, to judge whether the enterprises are family-controlled. Second, we apply manager's learning to family firms' financing decision-making and show that capital market plays an important role in managers' decision-making process, and the involvement of the family in business can reduce the probability of managers' learning on the whole. However, managers in family firms with low ownership level are more likely to ignore market feedback than those in family firms with high ownership level. Finally, we find no relation between the independent directors and managers' learning. And when family control is high enough to influence the firm's decision-making process but the ownership is very low, the family can tunnel the minority shareholders; when the families have both high control and high ownership of the firm, they act as stewards more than agents and will prop the firm. And the agency problems mainly exist between the family and the minority shareholders, which is consistent with the previous argument (Shleifer and Vishny, 1997; Burkart, Panunzi, and Shleifer, 2003; Morck and Yeung, 2003).

The remainder of this paper is as follows. Section II introduces the timeline of private placement and the information distribution after the announcement. Section III reviews previous literature and develops the hypotheses. Section IV is mainly focused on the sample and data, and presents the descriptive statistics. Section V presents the results. Section VI offers the robustness test results. Section VII concludes the paper. 


\section{PRIVATE PLACEMENT AND INFORMATION DISTRIBUTION}

Inspired by Luo (2005), we describe private placement according to its time order and analyze the information distribution after the announcement of private placement.

\section{The Timeline Of Private Placement}

\begin{tabular}{clll}
$\mathrm{T}=1$ & \multicolumn{1}{c}{$\mathrm{T}=2$} & \multicolumn{1}{c}{$\mathrm{T}=3$} & \multicolumn{1}{c}{$\mathrm{T}=4$} \\
Board meeting & $\begin{array}{l}\text { Managers observe } \\
\text { The market acquires } \\
\text { the information and } \\
\text { reacts to the } \\
\text { announcement. }\end{array}$ & $\begin{array}{l}\text { Closing: managers complete } \\
\text { the maction and }\end{array}$ & $\begin{array}{l}\text { reconsider the } \\
\text { recement according } \\
\text { to the announced plan or }\end{array}$ \\
previous decision.
\end{tabular}

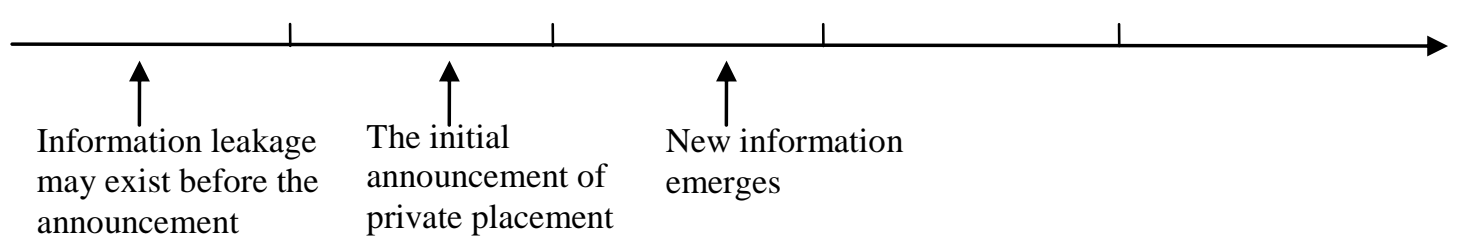

Figure 2: The Timeline Of Private Placement

Suppose the interest rate is zero and so the time value of money from the announcement day to the final decision day can be ignored. During private placement, there are several important time points: the announcement day of the board resolution, the announcement day of the shareholders' meeting, the announcement day of Securities Regulatory Commission (not provided), the announcement day of CSRC approval and the closing day. According to the information liquidity, there may be some information leakage between two announcement days. On the announcement day of the board resolution, it's the first time for outside investors to get the detailed information of private placement through the public channel. With more and more information announced, the placement becomes more and more obvious. Therefore, in order to eliminate the influence of the information leakage on the study, we select the announcement day of the board resolution as the initial announcement day.

However, the information leakage is inevitable. Prior to the initial announcement day, there may be some information leakage due to the supervision imperfection inside the company. Figure 2 presents the timeline of private placement. The initial announcement happens between time point 1 (the board meeting) and time point 2 (the market reaction). After the initial announcement, the market acquires the detailed information about the private placement (public information) at time point 2 and will analyze the current and future situation of the company. Then the market will react to the announcement. At time point 3, the managers will reconsider the previously announced plan based on the observation of market reaction. In fact, between time point 2 and time point 3, some new information will emerge and the interval between time point 1 and time point 2 is very short while the internal between time point 2 and time point 3 is very long. As a result, the companies and the market can fully exchange information. At time point 4 , if the company doesn't complete the placement according to the previously announced plan, it's more likely that the managers have accepted the feedback from the market, which means the managers learn from the capital market. We have to clarify that, because this study is mainly focused on the effect of the market reaction on the managers' final decisions, we put aside the information leakage and the emerging new information. 


\section{The Information Distribution After The Initial Announcement}

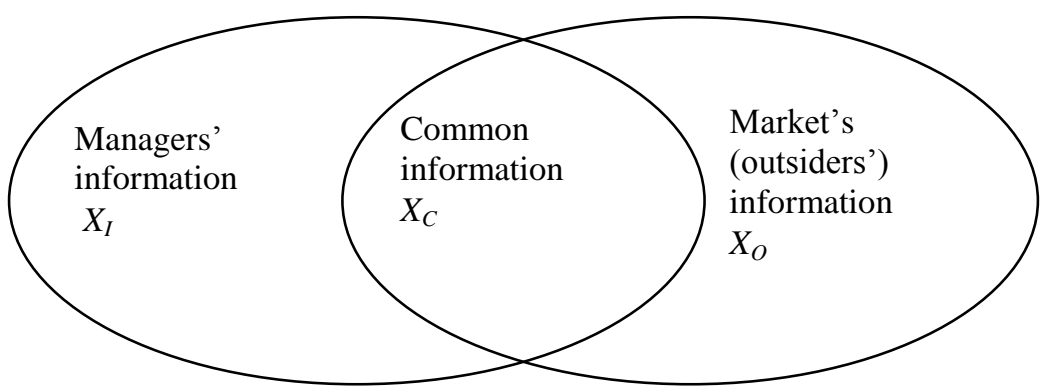

Figure 3: The Information Distribution After The Announcement

Figure 3 illustrates the information distribution between the managers and the market after the initial announcement of private placement. In tradition, the company announces part of the relative information to public, and keeps some private information as well. The market will then react to the announcement after acquiring the public information. In other words, the information can only flow from the insiders to the outsiders and thus the insiders' information subsumes the outsiders' information (in Figure 2, the $X_{O}$ is an empty set.). Dye and Sridhar (2002) claim that the information can flow not only from the company to the capital market but also from the capital market back to the company, which breaks the one way information flow in tradition. As they describe, traditional concept has ignored the market's ability in information processing. In fact, after acquiring the public information (such as the decision to implement private placement, the expected scale of raised fund and the feasibility report), the market can analyze $X_{C}$ and grasp the information not owned by the insiders ( $X_{O}$ is not an empty set). The information set $X_{I}$ owned by insiders is the managers' private information. Therefore, after the announcement, apart from the common information, both the managers and outside investors have the information not known by the other. Learning means that the managers accept all or part of the market's particular information $X_{O}$.

\section{THEORY AND HYPOTHESES}

Does managers' learning exist in private placement? What effect does the involvement of families in business have on managers' learning? Due to the strong ability in dealing with the public information, the capital market will generate much new information after observing the announcement of managers' decision and impound it into stock prices, passing on to the company (Dye and Sridhar, 2002; Luo, 2005; Kau, Linck, and Rubin, 2008; Aktas, de Bodt, and Roll, 2009, 2011). The managers will then extract useful information and learn from the market by way of adjusting the previously announced plan or implementing a new plan (Dye and Sridhar, 2002; Luo, 2005). However, the market signal may play a limited role in managers' major decision-making process (Blanchard, Rhee, and Summers, 1993), resulting from some factors such as the managers' overconfidence and self-interest behavior. Based on the study on the relation between the managers' decision-making and the market reaction, Jennings and Mazzeo (1991) point out that whether the managers learn from the market mainly depends on the amount of the private information they hold, which is also concluded by Luo (2005). And family firms are considered to have more opaque information than non-family firms (Faccio, Lang, and Young, 2001; Anderson, Duru, and Reeb, 2009), especially in emerging markets with poor protection for outside investors (Bertrand, Mehta, and Mullainathan, 2002). Thus, holding much private information, the managers in Chinese family firms may choose to ignore the market reaction to the announcement and harm the minority shareholders to seek private benefits. In other words, the managers in family firms are less likely to learn from the market.

Are there systematic differences in managers' learning between different levels of family ownership? Anderson and Reeb (2003) show that the positive effect from the family involvement in business starts to taper off when the family control rights exceed about $31 \%$. Family firms outperform non-family firms within some ownership range (Maury, 2006). Family control improves the performance at lower control level while dampens the performance at higher control level (Yeh, Lee, and Woidtke, 2001; Maury, 2006). When the control right is high enough for the family to impact the major decision-making process while the ownership is very low, the benefits of expropriating the minority shareholders outweigh the costs they bear. Under this circumstance, the decisions are usually taken in the interest of the family, which may go against the interests of the minority shareholders (Claessens 
et al., 2002; Villalonga and Amit, 2006; Anderson, Reeb, and Zhao 2012). In family firms with high ownership level, expropriation is less attractive for the high costs the families bear. Thereby, the family involvement in business may make the minority shareholders hurt when the family with little ownership has highly concentrated control rights.

Does the impact of family control on managers' learning vary with the corporate governance environment? First, Wu (2004) conducts a study on the properties of purchasers, concluding that the placements with managers participating in purchasing have more discounts than those without managers, and the discounts increase with the decrease of managers' holding proportion of companies' shares, indicating that the managers are self-interested. And the large shareholders having influence on the management may act in their interest which conflicts with the minority shareholders' (Woidtke, 2002). Therefore, when the families at full control of the firm with little ownership participate in purchasing the shares, they may make alliance with the managers who are not family members to transfer firms' profits to benefit themselves, hurting the minority shareholders (the condition is similar when the family members serve as the CEO or chairman of the board). Second, the independent directors on the board are responsible for the shareholders' interests, especially for the minority shareholders. They can help to reduce the families' opportunism (Anderson and Reeb, 2004) and mitigate the agency problems associated with expropriation and entrenchment (Setia-Atmaja, Haman, and Tanewski, 2011). So the regulatory authorities require appointing independent directors on the corporate board, and the proportion of the independent directors of family firms is higher than non-family firms in China (Cheng, 2014). Thus, we hypothesize that the independent directors may help restrict the managers' self-interest behavior and make the market reaction more influential on the firms' final decisions.

To summarize, the above discussion suggests the following hypotheses:

H1: Managers in family firms are less likely to learn from the market than those in non-family firms in private placement.

H2: Managers in family firms are less likely to learn from the market in private placement when the family controls the firm with little ownership.

H3: The impact of family control on managers' learning varies with the corporate governance environment:

H3a: When the family controls the firm with little ownership, the participation of family members in purchasing the shares can make the managers less likely to learn from the market.

H3b: When the family controls the firm with little ownership, the family member serving as CEO or Chairman of the board can make the managers less likely to learn from the market.

H3c: The independent directors can help to improve the probability of managers' learning from the market.

\section{SAMPLE AND SUMMARY STATISTICS}

\section{Sample And Data}

In order to study the influence of family control on managers' learning, we collected ultimate ownership data and corporate governance data from the CSMAR and WIND database, and the announcement day of board resolution from the report of the issuance of private placement or other similar reports announced by listed companies on the website $h t t p / / w w w . c n i n f o . c o m . c n$ from 2006 to 2013. We define family shareholdings as follows: the shares held by the family members, including the ones of blood and marriage ties, and the shares held by firms or other legal entities which are controlled by the family. After excluding the data of financial companies and the announcements with unknown results, we finally identify 1703 observations ${ }^{3}$.

For the family firms, we measure ultimate ownership with cash-flow rights, and ultimate controlled rights with voting rights. And the separation of control rights and the ownership is measured with the difference between ultimate controlled rights and ownership. Therefore, we trace the control chain of a firm and include both the direct and indirect shareholdings when we calculate the ultimate control rights of a family. For example, refer to figure 4,

\footnotetext{
${ }^{3}$ Here, the sample includes announcement from both the family firms and the non-family firms, including the state-owned firms and the sinoforeign joint venture.
} 
Firm A is a family firm and it owns $50 \%$ shares of Firm B, and Firm B owns $40 \%$ shares of Firm C, and Firm C owns $30 \%$ shares of Firm D. Then, A has $6 \%$ ownership of Firm D, and 30\% control rights of Firm D. ${ }^{4}$

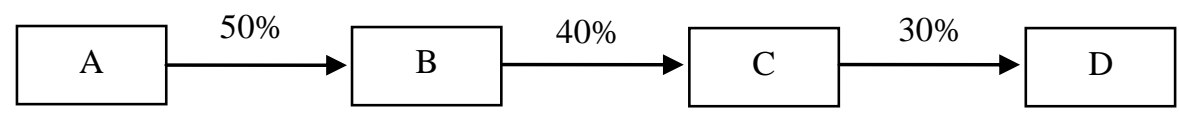

Figure 4: The Calculation Of Ultimate Controlled Rights And The Ownership

\section{Definition Of Family Firms}

Most of previous studies on family firms base the ultimate control of the families on 5\% (Villalonga and Amit, 2006; Anderson, Reeb, and Zhao, 2012; McGuire, Dow, and Ibrahim, 2012), 10\% (La Porta, Lopez-deSilanes, and Shleifer, 1999; Maury, 2006) and 20\% (La Porta, Lopez-de-Silanes, and Shleifer, 1999; Faccio and Lang, 2002) cut-offs. However, their studies are mainly concentrated in European and American firms, which are very different from the ones in China. In China, the state-owned enterprises and private-owned firms are the main business forms. So removing the constraint of family control rights, we define the family firms as follows: if the business is ultimately controlled by one family or several connected families or natural individuals, then it is a family firm ${ }^{5}$.

Table 2 is the announcements clustered by the companies' industry. From 2006 to 2013, as one mode of refinancing, the private placement is very common, especially in large industries, such as manufacturing.

Table 2: The Announcement Of Private Placement Clustered By The Industry

\begin{tabular}{|c|c|c|c|c|c|c|}
\hline \multicolumn{4}{|c|}{ Industry } & Total & $\begin{array}{c}\text { Family } \\
\text { Firms }\end{array}$ & $\begin{array}{l}\text { Non-Family } \\
\text { Firms }\end{array}$ \\
\hline \multicolumn{4}{|c|}{ A. Agriculture, forestry, animal husbandry, side-line production and fishery } & 31 & 15 & 16 \\
\hline \multicolumn{4}{|c|}{ B. Mining and Quarrying } & 60 & 23 & 37 \\
\hline \multicolumn{4}{|c|}{ C. Manufacturing } & 1055 & 509 & 546 \\
\hline \multicolumn{4}{|c|}{ D. Electric power, Gas and Hydraulic production and supply } & 91 & 11 & 80 \\
\hline \multicolumn{4}{|c|}{ E. Construction } & 46 & 20 & 26 \\
\hline \multicolumn{4}{|c|}{ F. Transportation and Warehousing } & 64 & 8 & 56 \\
\hline \multicolumn{4}{|c|}{ G. Information technology } & 111 & 60 & 51 \\
\hline \multicolumn{4}{|c|}{ H. Wholesale and retail trade } & 94 & 46 & 48 \\
\hline \multicolumn{4}{|c|}{ J. Real estate } & 23 & 14 & 9 \\
\hline \multicolumn{4}{|c|}{ K. Social services } & 57 & 23 & 34 \\
\hline \multicolumn{4}{|c|}{ L. Communication and cultural industries } & 31 & 4 & 27 \\
\hline \multicolumn{4}{|c|}{ M. Comprehensive } & 40 & 24 & 16 \\
\hline \multicolumn{7}{|c|}{$\begin{array}{l}\text { Note: The classification of industry is according to the CSRC (China Securities Regulatory Commission) industry classification. We have } \\
\text { excluded the financial companies from the sample. }\end{array}$} \\
\hline \multicolumn{7}{|c|}{$\begin{array}{l}\text { Table } 3 \text { presents the announcements of private placement from different type of business after we identify } \\
\text { the family firms. }\end{array}$} \\
\hline \multicolumn{7}{|c|}{ Table 3: The Announcements From Different Business Type } \\
\hline \multirow{2}{*}{ Announcements } & \multirow{2}{*}{ State-Owned } & \multicolumn{2}{|c|}{ Family Firms $^{6}$} & \multirow{2}{*}{\multicolumn{2}{|c|}{ Sino-Foreign Joint }} & \multirow{2}{*}{ Total } \\
\hline & & High Separation & Low Separation & & & \\
\hline Number & 925 & 391 & 366 & & & 1703 \\
\hline Percentage & $54.32 \%$ & $22.96 \%$ & $21.49 \%$ & & & $100.00 \%$ \\
\hline
\end{tabular}

\footnotetext{
${ }^{4}$ According to Claessens, Djankov, and Lang (2000), we calculate the ownership as $50 \% * 40 \% * 30 \%=6 \%$ and ultimate control rights as min $(50 \%, 40 \%, 30 \%)=30 \%$.

${ }^{5} \mathrm{We}$ also use the fixed and float cut-offs to judge whether the business is family-controlled. The discussion is in our robustness tests.

${ }^{6}$ If the separation of control rights and ownership exceeds the median value for the sample of family-controlled firms, then it is classified into sample with high separation of the two rights; otherwise, it is classified into sample with low separation of the two rights.
} 
We find that approximately $54 \%$ of the announcements are from the state-owned companies and $45 \%$ are from the family firms and the remaining $1 \%$ is from the sino-foreign joint venture.

\section{The Method}

We use event study to examine the market reaction to the initial announcement and obtain the $C A R$ (cumulative abnormal return) by estimating the following market model:

$R_{i t}=\alpha_{i}+\beta_{i} R_{M t}+\varepsilon_{i t}$

where $R_{i t}$ is the real daily stock return, $R_{M t}$ is the average daily return of the value-weighted market portfolio, and $\varepsilon_{i t}$ is the daily abnormal return. We select the days $[-240,-10]$ before the initial announcement day as the estimation period. The announcement day of board resolution is selected as the pricing benchmark day. If the stocks are suspended on that day, then the first trading day after the announcement is selected as the benchmark day. And -1 to 3 days around the announcement day is selected as the event window ${ }^{7}$.

Table 4: The Definition Of The Variables

\begin{tabular}{|c|c|}
\hline Variables & Definition \\
\hline \multicolumn{2}{|c|}{ A:Governance characteristics } \\
\hline Ownership by the family & $\begin{array}{l}\text { (The shares held by the family members }+ \text { shares held by other entities controlled by the } \\
\text { family)/The firms' total number of shares. }\end{array}$ \\
\hline Separation & The separation of control rights and ownership. \\
\hline Serve & It equals 1 if the family members serve as the CEO or chairman of the board; otherwise it equals 0 . \\
\hline Independent & The number of independent directors/ the total number of the board. \\
\hline \multicolumn{2}{|c|}{ B:The characteristics of the private placement } \\
\hline Complete & $\begin{array}{l}\text { Dependent variable. Dummy variable. It equals } 1 \text { if the firm finally completes the announced } \\
\text { decision; otherwise it equals } 0 .\end{array}$ \\
\hline CAR & $\begin{array}{l}\text { Market reaction to the announcement. It is the cumulative abnormal return from }-1 \text { to } 3 \text { days } \\
\text { around the announcement day. }\end{array}$ \\
\hline Part & It equals 1 if the family members participate in purchasing the placed shares; otherwise it equals 0 . \\
\hline Frac $(\%)$ & The number of the shares placed/The firms' total shares after placing. \\
\hline $\operatorname{Disct}(\%)$ & $\begin{array}{l}\text { (The stock price at the announcement day-The announced price)/The stock price at the } \\
\text { announcement day. }\end{array}$ \\
\hline \multicolumn{2}{|l|}{ C:Firm characteristics } \\
\hline Lev $(\%)$ & The firm's leverage rate last year. \\
\hline Lnsize & The natural log of the firm's total assets. \\
\hline Mkt $(\%)$ & The average market return from -60 to -1 days before the announcement day. \\
\hline $\mathrm{ROA}(\%)$ & The firm's latest net margin before the announcement day/The firm's total assets. \\
\hline Growth $(\%)$ & The firms' sales growth last year. \\
\hline Liquid & The outstanding shares/the firms' total shares before the announcement day. \\
\hline
\end{tabular}

In order to examine the effect of family control on managers' learning, first, we investigate the relation between managers' final decisions and the market reaction, examining the existence of managers' learning in private placement. And the family involvement in business can reduce the probability of managers' learning. Second, the sample of family firms is divided into two subsamples: the sample with high separation of control rights and ownership and sample with low separation of control rights and ownership. If the separation of the two rights exceeds the median value for the sample of family firms, then it is classified into sample with high separation of the two rights; otherwise, it is classified into sample with low separation of the two rights. We then examine managers' learning in the two subsamples, respectively. Third, we examine the role of corporate governance in managers' learning. Finally, we do a robust test to further examine managers' learning in family firms.

\footnotetext{
${ }^{7}$ In China, the interval between board meeting and shareholder meeting is generally at least 15 days. Too long event window may lead the results disturbed by shareholder meeting announcement and the information leakage. And for robustness, we also use $[-1,1],[-1,5]$ and $[-1,10]$ days as the event window, the results are stable.
} 


\section{The Models And Variables}

As the market reaction to the announcement $(C A R)$ is influenced by many factors, such as the firms' profitability, the firm's capital structure and the micro-environment, we adopt 2SLS (two-stage least squares) model to investigate managers' learning in private placement to control for endogeneity effects. In the first-stage regression, we seek some factors affecting the market reaction $(C A R)$ and then use the predicted values as explanatory variables in the second-stage regression. Note that the control variables in the second stage must be included in the first stage and some factors affecting CAR may be the same with the control variables. The 2SLS model is as follows:

First-stage:

$C A R=\beta+\alpha_{1}$ Lev $+\alpha_{2}$ Frac $+\alpha_{3}$ Disct $+\alpha_{4}$ Mkt $+\alpha_{5}$ Lnsize $+\alpha_{6}$ Growth $+\alpha_{7}$ Liquid $+\alpha_{8}$ ROA

Second-stage:

Logit $($ Complete $)=\beta+\alpha_{1}$ CAR $+\alpha_{2}$ Family $+\alpha_{3}$ CAR $\times$ Family $+\alpha_{4} Q_{1}$

where $Q_{1}$ includes Lev, Lnsize, Disct, ROA, Mkt. The meaning of the variables is presented in Table 4.

Table 5: Summary Statistics Of The Variables

\begin{tabular}{lccccc}
\hline \multicolumn{1}{c}{ Variables } & Mean & Median & S.D. & Min & Max \\
\hline A: Governance characteristics & & & & & \\
Ultimate ownership by the family (\%) & 25.64 & 21.84 & 16.64 & 7.18 & 49.88 \\
Ultimate control by the family (\%) & 32.99 & 29.95 & 16.64 & 13.83 & 56.83 \\
The separation of the two rights & 7.35 & 4.07 & 8.41 & 0.00 & 19.70 \\
Serve & 0.55 & 1.00 & 0.50 & 0.00 & 1.00 \\
Independent & 0.36 & 0.33 & 0.04 & 0.33 & 0.43 \\
\hline B: The characteristics of private placement & & & & & \\
Complete & 0.63 & 1.00 & 0.48 & 0.00 & 1.00 \\
CAR & 0.05 & 0.02 & 0.10 & -0.08 & 0.26 \\
Part & 0.41 & 0.00 & 0.49 & 0.00 & 1.00 \\
Frac(\%) & 0.26 & 0.20 & 0.17 & 0.08 & 0.62 \\
Disct(\%) & 0.23 & 0.14 & 0.33 & -0.13 & 1.00 \\
\hline C: Firm characteristics & & & & & \\
Lev (\%) & 0.52 & 0.51 & 0.20 & 0.24 & 0.83 \\
Lnsize & 11.77 & 11.73 & 0.88 & 10.36 & 13.15 \\
Mkt(\%) & 0.01 & 0.01 & 0.06 & -0.08 & 0.11 \\
ROA (\%) & 3.72 & 3.12 & 3.28 & -0.78 & 9.63 \\
Growth (\%) & 0.20 & 0.17 & 0.26 & -0.17 & 0.64 \\
Liquid & 0.64 & 0.61 & 0.27 & 0.25 & 1.00 \\
\hline
\end{tabular}

\section{Descriptive Statistics}

Table 5 presents the summary statistics of the variables. The sample includes family firms only. On average, the families have about $26 \%$ ownership and $33 \%$ control rights of the business. The separation of the two rights is about $7 \%$. On the whole, family members serve as the CEO or chairman of the board in more than half of the firms (55\%). About $63 \%$ of the announced plans are finally completed and the market reaction to the announcement is positive on average, which is consistent with most of the previous studies on the announcement effects of private placement (Tan, Chng, and Tong, 2002; Hertzel et al., 2002). And about $41 \%$ of the private placements have family members participating in purchasing the placed shares.

\section{RESULTS AND DISCUSSION}

In this section, we proceed with empirical tests investigating (1) the general relationship between the market reaction to the announced financing plan and the managers' final decision on whether the plan is ultimately 
implemented or not (whether the managers learn from the market); (2) whether the family involvement in business affects managers' learning; (3) and whether the relation varies with some characteristics of family firm and the financing plan. We winsorize all the variables at $1 \%$ level to minimize the effect of outliers on the results. And the reported robust standard errors are clustered at firm level and correct for heteroscedasticity.

\section{The Relation Between Family Control And Managers' Learning}

It is well accepted that family firms have some unique characteristics in governance. So what effect does family involvement in business bring to managers' learning? Table 6 reports the regression results which address this question.

\begin{tabular}{|c|c|c|}
\hline Variables & Test 1 & Test 2 \\
\hline Constant & $-1.69 * *(0.844)$ & $-3.33 * *(1.317)$ \\
\hline CAR & $0.60 * *(0.292)$ & $4.16 * *(1.657)$ \\
\hline CAR $*$ Family & & $-3.79 * *(1.622)$ \\
\hline Family & & $0.39 * *(0.180)$ \\
\hline Lev & $-1.47 *(0.416)$ & $-1.60 * * *(0.514)$ \\
\hline Disct & $-3.93 *(0.228)$ & $-4.03 * * *(0.249)$ \\
\hline Lnsize & $0.24 * * *(0.067)$ & $0.35 * * *(0.111)$ \\
\hline Mkt & $0.30(0.919)$ & $-0.74(1.072)$ \\
\hline ROA & $0.09 * * *(0.022)$ & $0.083 * * *(0.023)$ \\
\hline Industry & YES & YES \\
\hline Observations & 1703 & 1703 \\
\hline$\chi^{2}$ & 332.62 & 324.05 \\
\hline$\stackrel{n}{\mathrm{P}}\left(\chi^{2}\right)$ & 0.000 & 0.000 \\
\hline R-Squared & 0.187 & 0.184 \\
\hline \multicolumn{3}{|c|}{$\begin{array}{l}\text { Note: } *, * *, * * * \text { are respectively significant at } 10 \%, 5 \% \text { and } 1 \% \text { level. The numbers in parentheses are Robust standard errors. CAR is the } \\
\text { cumulative abnormal return to the announcement from }-1 \text { to } 3 \text { days around the announcement day; the sample includes both the family and } \\
\text { non-family firms. Note that we adopt the } 2 \text { SLS model: the variable CAR is estimated from equation (2) and the predicted value is then used as } \\
\text { explanatory variable in the second-stage regression: Logit (Complete) }=\beta+\alpha_{l} C A R+\alpha_{2} \text { Family }+\alpha_{3} \text { CAR } \times \text { Family }+\alpha_{4} Q_{l} \text {. }\end{array}$} \\
\hline
\end{tabular}

As the results show, the coefficient of CAR in Test 1 is significantly positive at 5\% level, indicating that when making final decisions, the managers will generally learn from the market. After observing the announced information of the private placement, the stock market can generate some new information that guides the managers' final decisions. In Test 2, the coefficient of CAR is still significantly positive while the cross variable is significantly negative at 5\% level, showing that family involvement in business can make the managers less likely to learn from the market. Different from the view that family firms pay more attention to their reputation and economic outcomes of the decisions when they refinance (La Porta et al., 2000), our results instead suggest that family firms tend to ignore the market reaction and may have some opportunistic behavior when they make final decisions as discussed in Section III. Can we say that the managers in family firms don't learn from the market when making the final financing decisions? The following analysis addresses this question. 
Table 7: Regressions Of Managers' Learning With Different Separation Level Of The Two Rights In Family Firms

\begin{tabular}{|c|c|c|c|c|}
\hline \multirow{2}{*}{ Variables } & Test 1 & Test 2 & Test 3 & Test 4 \\
\hline & Family firms & High-separation & Low-separation & Family firms \\
\hline Constant & $-3.64 * *(1.509)$ & $-2.01(2.436)$ & $-4.75 * *(2.200)$ & $-3.97 * *(1.542)$ \\
\hline CAR & $0.32(0.246)$ & $-0.76(0.747)$ & $3.55 * * *(1.263)$ & $3.55 * * *(1.246)$ \\
\hline Highseparation*CAR & & & & $-4.27 * * *(1.483)$ \\
\hline Highseparation & & & & $0.44 * *(0.205)$ \\
\hline Lev & $-2.31 *(0.589)$ & $-3.72 * * *(0.867)$ & $-1.47(0.895)$ & $-2.50 *(0.614)$ \\
\hline Disct & $-3.74 * * *(0.280)$ & $-3.76 * * *(0.411)$ & $-3.72 * * *(0.403)$ & $-3.70 *(0.283)$ \\
\hline Lnsize & $0.43 * * *(0.121)$ & $0.40 * *(0.187)$ & $0.41 * *(0.175)$ & $0.44 * * *(0.122)$ \\
\hline Mkt & $-0.20(1.579)$ & $0.04(2.223)$ & $-0.66(2.489)$ & $-0.22(1.593)$ \\
\hline ROA & $0.06 * *(0.030)$ & $0.10 * *(0.044)$ & $0.05(0.048)$ & $0.07 * *(0.031)$ \\
\hline Industry & YES & YES & YES & YES \\
\hline Observations & 757 & 391 & 366 & 757 \\
\hline$\chi^{2}$ & 200.13 & 100.45 & 101.15 & 194.79 \\
\hline$\stackrel{\sim}{\mathrm{P}}\left(\chi^{2}\right)$ & 0.000 & 0.000 & 0.000 & 0.000 \\
\hline $\mathrm{R}$-Squared & 0.245 & 0.259 & 0.277 & 0.259 \\
\hline
\end{tabular}

Note: *, **, *** are respectively significant at $10 \%, 5 \%$ and $1 \%$ level. The numbers in parentheses are Robust standard errors. CAR is the cumulative abnormal return to the announcement from -1 to 3 days around the announcement day. Test 1 is for the sample of family firms; test 2 is for the subsample of family firms with high separation of the two rights; test 3 is for the subsample of family firms with low separation of the two rights. If the firm's separation of the two rights exceeds the median value for the sample of family firms, then it is classified into sample with high separation; otherwise, it is classified into sample with low separation. Note that we adopt the 2SLS model: CAR is estimated from equation (2) and the predicted value is then used as explanatory variable in the second-stage regressions.

Table 7 reports the results of a multivariate analysis examining whether managers learn from the market in family firms after controlling for some factors. The coefficients of CAR in Test 1 is positive but not significant, suggesting that the market feedback to the announcement don't have effect on managers' final decisions in family firms on the whole. One explanation for the insignificance is that managers' learning exists in one subsample while not in the other one, resulting in the effect mitigated in the whole sample. As we discussed in Section III, the level of separation of control rights and ownership may affect managers' behavior in family firms. To investigate this possibility, we rerun the regression for the subsamples of family firms with high separation of the two rights and with low separation of the two rights, respectively. The coefficient of CAR is significantly positive in Test 3 but insignificant in Test 2, indicating that the separation of family's control rights and ownership can indeed influence the managers' behavior, which is consistent with the discussion in Section III.

To make the results more convincible, we create a dummy variable: Highseparation, which equals 1 if the separation of the family's control rights and ownership exceeds the median value for the sample with family firms, otherwise it equals 0 . In Test 4 , we mainly focus on the variable $C A R$ and the cross term. The coefficient of $C A R$ and the cross term are significantly positive and negative, respectively. The results suggest that family firms with low levels of ownership can reduce the possibility of managers' learning. The results in Tables 6 and 7 indicate that family firms with low levels of ownership appear to be most likely to expropriate the minority shareholders. There is a trade-off between the benefits of expropriation and the costs they bear. Under this circumstance, they may ignore the market feedback and carry out the previous plans to maximize the families' utility instead of the firm value for all shareholders. Thus, it would be incorrect to conclude that the families always act as stewards who act farsightedly in the interest of both family and non-family shareholders. These are consistent with the notion that family opportunism increases when the family effectively controls the firm but the ownership is not high enough to make the tunneling costly.

\section{The Role Of Corporate Governance}

Now that the interest conflict between the family and the minority shareholders dominate when the family with low ownership controls the firm as we have analyzed, what influence do the characteristics of corporate governance have on managers' learning? Are there any effective approaches to restrain managers to maximize firm value for all shareholders? The tests in Table 8-1 investigate this issue.

In Tests 1 through 3, we respectively create a cross term and the regression of Test 4 includes the entire cross terms. The sample includes the family firms with high separation of control rights and ownership only. From 
the results, several interesting findings emerge: (a) family members' participation in purchasing the placed shares can reduce the managers' tendency to learn from the market (the coefficient of CAR*Part is significantly negative); (b) when family members serve as the CEO or chairman of the board, managers are less likely to consider the market feedback when they make final decisions (the coefficient of $C A R^{*}$ Serve is significantly negative); (c) the independent directors in family firms have no influence on managers' learning (the coefficient of CAR*Independent is positive but insignificant). Taken as a whole, when the family dominates the firm with little ownership (pyramiding structure), the managers may align with the family to expropriate the minority shareholders, thus realizing their private benefits. Although the responsibility of the independent directors is to monitor the firms' management, the independent directors don't play their due role in private placement. The results in Test 4 also have the same conclusions which are consistent with our discussion in Section III.

Table 8-1: The Effect Of Corporate Governance On Managers' Learning

\begin{tabular}{|c|c|c|c|c|}
\hline \multirow{2}{*}{ Variables } & \multicolumn{4}{|c|}{ High-Separation } \\
\hline & Test 1 & Test 2 & Test 3 & Test 4 \\
\hline Constant & $-1.69(2.425)$ & $-1.51(2.525)$ & $-4.20(2.708)$ & $-1.50(2.733)$ \\
\hline CAR & $-0.88(1.635)$ & $-0.25(0.661)$ & $-1.62(4.570)$ & $0.27(2.372)$ \\
\hline CAR $*$ Part & $-7.56 *(4.381)$ & & & $-7.87 *(4.406)$ \\
\hline Part & $0.37(0.341)$ & & & $0.42(0.350)$ \\
\hline CAR*Serve & & $-2.91 *(1.653)$ & & $-2.20 *(1.832)$ \\
\hline Serve & & $0.46(0.305)$ & & $0.43(0.323)$ \\
\hline CAR*Independent & & & $9.73(8.975)$ & $0.52(2.620)$ \\
\hline Independent & & & $-1.39(2.722)$ & $-0.61(3.227)$ \\
\hline Lev & $-3.63 * * *(0.872)$ & $-3.26 * * *(0.859)$ & $-1.37(0.861)$ & $-3.37 * * *(0.881)$ \\
\hline Disct & $-3.78 * * *(0.424)$ & $-3.64 * * *(0.427)$ & $-3.77 * * *(0.407)$ & $-3.77 * * *(0.435)$ \\
\hline Lnsize & $0.37 * *(0.181)$ & $0.32 *(0.191)$ & $0.41 * *(0.178)$ & $0.34 *(0.185)$ \\
\hline Mkt & $0.43(2.247)$ & $0.27(2.254)$ & $-1.16(2.530)$ & $0.69(2.259)$ \\
\hline ROA & $0.085 *(0.044)$ & $0.08 *(0.043)$ & $0.045(0.048)$ & $0.082 *(0.0441)$ \\
\hline Industry & YES & YES & YES & YES \\
\hline Observations & 391 & 391 & 391 & 391 \\
\hline$\chi^{2}$ & 95.09 & 91.21 & 101.00 & 93.55 \\
\hline$\stackrel{\tilde{P}}{\mathrm{P}}\left(\chi^{2}\right)$ & 0.000 & 0.000 & 0.000 & 0.000 \\
\hline R-Squared & 0.263 & 0.258 & 0.266 & 0.268 \\
\hline
\end{tabular}

Note: *,**,*** are respectively significant at $10 \%, 5 \%$ and $1 \%$ level. The numbers in parentheses are Robust standard errors. CAR is the cumulative abnormal return to the announcement from -1 to 3 days around the announcement day. The sample includes family firms with high separation of control rights and ownership only. If the firm's separation of the two rights exceeds the median value for the sample of family firms, then it is classified into sample with high separation; otherwise, it is classified into sample with low separation. Note that we adopt the 2SLS model: CAR is estimated from equation (2) and the predicted value is then used as explanatory variable in the second-stage regressions.

To confirm this, we rerun the regressions to examine the role of the above characteristics in the subsample of family firms with low separation of control rights and ownership. Table 8-2 reports the results.

The coefficients of CAR in Tests 5 through 8 are all significantly positive, which are consistent with the results in Table 7, implies the existence of managers' learning in family firms with low separation of control rights and ownership. Interestingly however, all the coefficients of the cross terms turns insignificant. The results in Table 8-2 show that our analysis of managers' behavior in family firms is reasonable. When the family controls the firm with pyramiding structure, they act as agents and the minority shareholders' interest may be hurt; when the family controls the firm with high ownership, they act as stewards more than agents, thus they make decisions to maximize the firm value for both the family and the minority shareholders. 
Table 8-2: The Effect Of Corporate Governance On Managers' Learning

\begin{tabular}{|c|c|c|c|c|}
\hline \multirow{2}{*}{ Variables } & \multicolumn{4}{|c|}{ Low-Separation } \\
\hline & Test 5 & Test 6 & Test 7 & Test 8 \\
\hline Constant & $-4.57 * *(2.275)$ & $-4.67 * *(2.171)$ & $-4.94 *(2.953)$ & $-4.20(3.004)$ \\
\hline CAR & $3.76 * *(1.858)$ & $4.50 * * *(1.596)$ & $5.56 *(3.369)$ & $12.57 *(8.222)$ \\
\hline CAR*Part & $-2.30(5.157)$ & & & $-0.87(4.952)$ \\
\hline Part & $-0.34(0.357)$ & & & $-0.35(0.367)$ \\
\hline CAR*Serve & & $-3.82(2.658)$ & & $-4.19(2.644)$ \\
\hline Serve & & $1.03 * * *(0.314)$ & & $1.03 * * *(0.315)$ \\
\hline CAR*Independent & & & $-11.25(12.250)$ & $-20.63(21.810)$ \\
\hline Independent & & & $0.34(3.662)$ & $0.10(3.896)$ \\
\hline Lev & $-1.29(0.865)$ & $-0.96(0.902)$ & $-1.41(0.863)$ & $-0.98(0.907)$ \\
\hline Disct & $-3.71 * * *(0.408)$ & $-3.93 * * *(0.427)$ & $-3.79 * * *(0.411)$ & $-3.94 * * *(0.435)$ \\
\hline Lnsize & $0.40 * *(0.176)$ & $0.36^{* *}(0.172)$ & $0.43 * *(0.179)$ & $0.35 *(0.181)$ \\
\hline Mkt & $-1.25(2.494)$ & $-1.27(2.675)$ & $-0.64(2.567)$ & $-1.37(2.757)$ \\
\hline ROA & $0.05(0.048)$ & $0.05(0.050)$ & $0.04(0.047)$ & $0.04(0.050)$ \\
\hline Industry & YES & YES & YES & YES \\
\hline Observations & 366 & 366 & 366 & 366 \\
\hline$\chi^{2}$ & 98.87 & 101.61 & 101.06 & 98.26 \\
\hline$\tilde{\mathrm{P}}\left(\chi^{2}\right)$ & 0.000 & 0.000 & 0.000 & 0.000 \\
\hline R-Squared & 0.272 & 0.295 & 0.275 & 0.301 \\
\hline $\begin{array}{l}\text { Note: } *, * *, * * * \text { are res } \\
\text { cumulative abnormal re } \\
\text { separation of control rig } \\
\text { then it is classified into } \\
\text { model: the variable } C A P \\
\text { regressions. }\end{array}$ & $\begin{array}{l}\text { significant at } 10 \% \text {, } \\
\text { e announcement fro } \\
\text { wnership only. If th } \\
\text { ith high separation; } \\
\text { ated from equation }\end{array}$ & $\begin{array}{l}\% \text { level. The numbe } \\
\text { days around the ann } \\
\text { on of the two rights } \\
\text { e, it is classified into } \\
\text { e predicted value is }\end{array}$ & $\begin{array}{l}\text { ntheses are Robust s } \\
\text { nt day. The sample } \mathrm{i} \\
\text { the median value for } \\
\text { vith low separation. } \\
\text { as explanatory varia }\end{array}$ & $\begin{array}{l}\text { errors. CAR is the } \\
\text { family firms with low } \\
\text { ple of family firms, } \\
\text { t we adopt the } 2 S L S \\
\text { e second-stage }\end{array}$ \\
\hline
\end{tabular}

\section{The Definition Of Family Firms}

\section{ROBUSTNESS TESTS}

Inspired by the early studies on family firms, we use another two different approaches to define a family firm in this section.

\section{The Fixed Cut-Offs}

Most of previous studies on family firms use fixed cut-off of families' ultimate control, such as $5 \%, 10 \%$ and $20 \%$, to judge whether it is family-controlled. It's well accepted that deeply influenced by Confucius culture, the Chinese firms have relatively concentrated equity structure. So we rerun the regressions using $20 \%$ as a fixed cut-off point of family control to identify a family firm. As a result, two conditions are needed to judge whether the firm is family-controlled: (a) the firm is ultimately controlled by a family or a natural individual; and (b) the sum of direct and indirect ownership of the controlling family exceeds $20 \%$. 574 announcements from family firms are finally identified compared with 757 in our previous analysis.

\section{Float Cut-Offs}

The fixed cut-offs of control level are insufficient in considering a firm's ownership distribution (Yeh, Lee, and Woidtke, 2001). For instance, the cut-off of 5\% ownership may be too low for highly-concentrated firms and $20 \%$ may be too high for widely-held firms. To solve this issue, referring to Yeh, Lee, and Woidtke (2001), we calculate the firm's floating cut-offs of control level as follows,

$$
C^{*}=Z_{\alpha} * \sqrt{\frac{\pi * H}{1+Z_{\alpha}^{2} * \pi}}
$$


where $C^{*}$ is the cut-off of control level; $Z_{\alpha}$ is the $z$-value meeting the condition $P(z \leq Z)=\alpha$ in a Normal Distribution; $\alpha$ denotes the possibility of winning the vote for the family at a shareholding meeting; $\pi$ denotes the possibility of exercising the vote; And $H$ is the Herfindahl index of ownership concentration within a family firm. We calculate the Herfindahl index using the top10 shareholders' holding rate:

$H=\sum_{i=1}^{k} P_{i}$

where $P_{i}$ is the total percentage shareholdings of the $i$ th shareholder. For we are interested in families' absolute control of a firm, we respectively set $\alpha=0.999$ and $\pi=1$ such that the family can win the vote at a shareholder meeting with almost certain and the shareholders always excise their voting rights. Therefore, we can see that higher expect to win the vote requires higher ownership concentration within a firm. As a result, two conditions are needed to judge whether the firm is family-controlled: (a) it is ultimately controlled by a family or natural individuals; and (b) the sum of direct and indirect ownership of the controller exceeds the cut-offs of the control level which is calculated by equation (4). Thus, each firm has a cut-off point of control level and this is just why we call it float cut-offs. On average, $10.42 \%$ control level is required to effectively control the firm compared with the levels of $5 \%, 10 \%$ and $20 \%$ used in previous studies. 655 announcements from family firms are finally identified.

The results are reported in Table 9. The effects of family involvement in business and the separation level of two rights on managers' learning are both consistent with our previous analysis. Interestingly, both of the effects taper with the increase of the cut-offs (the effect of family involvement: -3.786 in Table 6, -3.048 in Test 1 in Table 9 and -1.344 in Test 3 in Table 9; the effect of separation level: -4.267 in Table 6, -0.461 in Test 2 in Table 9 and 0.369 in Test 4 in Table 9). The results suggest that the cut-off level to identify a family firm is much relevant when studying the relation between family control and managers' learning. However the previous studies on family firm have not reached a consensus on how to identify a family firm. In our opinion, the definition of family firm varies with situations in different countries.

\section{Sample Processing}

In our previous analysis on the effect of family involvement on managers' learning, the subsample of nonfamily firms includes both the state-owned enterprises and sino-foreign joint venture. For we mainly focus on managers' learning in the local enterprises, there may be some bias on the results. So for robustness, we remove the sino-foreign joint venture (21 observations) from our sample. The results are reported in Table 10. The coefficients of $C A R$ in Tests 1 and 2 are both significantly positive and the coefficient of the cross term CAR*Family is significantly negative, which accords with our previous results. Overall, the effect of family control seems to be more pronounced to the exclusion the sino-foreign joint venture in the sample. 
Table 9: Regressions Of Managers' Learning In Family Firms According To The Fixed And Floating Cut-Offs

\begin{tabular}{|c|c|c|c|c|}
\hline \multirow{2}{*}{ Variables } & \multicolumn{2}{|c|}{ Fixed Cut-Offs } & \multicolumn{2}{|c|}{ Floating Cut-Offs } \\
\hline & Test 1 & Test 2 & Test 3 & Test 4 \\
\hline Constant & $-3.49 * * *(1.301)$ & $-2.12(1.859)$ & $-1.93 * *(0.918)$ & $-2.57(1.579)$ \\
\hline CAR & $3.44 * *(1.561)$ & $0.51(0.399)$ & $1.44 * *(0.579)$ & $-0.94(1.177)$ \\
\hline CAR $*$ Family & $-3.05 *(1.726)$ & & $-1.34 *(0.702)$ & \\
\hline Family & $0.42 * *(0.191)$ & & $0.11(0.140)$ & \\
\hline Highseparation*CAR & & $-0.46 *(0.263)$ & & $-0.37 *(0.213)$ \\
\hline Highseparation & & $-0.87(2.373)$ & & $0.51(0.445)$ \\
\hline Lev & $-1.67 * * *(0.513)$ & $-2.88 * * *(0.792)$ & $-1.47 * * *(0.417)$ & $-2.65 * * *(0.661)$ \\
\hline Disct & $-4.04 * * *(0.250)$ & $-4.45 * * *(0.419)$ & $-3.92 * * *(0.230)$ & $-4.31 * * *(0.362)$ \\
\hline Lnsize & $0.37 * * *(0.110)$ & $0.37 * *(0.150)$ & $0.25^{* * *}(0.0713)$ & $0.40 * * *(0.131)$ \\
\hline Mkt & $-0.57(1.066)$ & 1.94(1.729) & $0.16(0.918)$ & 1.30(1.598) \\
\hline ROA & $0.082 * * *(0.023)$ & $0.09 * *(0.038)$ & $0.09 * * *(0.022)$ & $0.08 * *(0.034)$ \\
\hline Industry & YES & YES & YES & YES \\
\hline Observations & 1703 & 574 & 1703 & 655 \\
\hline$\chi^{2}$ & 324.34 & 136.42 & 330.5 & 164.59 \\
\hline $\mathrm{P}\left(\chi^{2}\right)$ & 0.00 & 0.00 & 0.000 & 0.000 \\
\hline R-Squared & 0.180 & 0.262 & 0.189 & 0.244 \\
\hline
\end{tabular}

Note: $*, * *, * *$ are respectively significant at $10 \%, 5 \%$ and $1 \%$ level. The numbers in parentheses are Robust standard errors. CAR is the cumulative abnormal return to the announcement from -1 to 3 days around the announcement day. In Tests 1 and 2 , we calculate a cut-off for each firm to judge whether it is family-controlled. In Tests 3 and 4, we use $20 \%$ as the cut-off point to identify a family firm. Note that we adopt the 2SLS model: the variable CAR is estimated from equation (2) and the predicted value is then used as explanatory variable in the second-stage regressions.

\section{The Market Reaction}

For robustness, we check the sensitivity of the results using different event windows to measure the market reaction. That is, we substitute $\operatorname{CAR}(-1,3)$ with $C A R(-1,1), C A R(-1,5)$ and $C A R(-1,10)$, respectively. The results are all similar, although the ones with $\operatorname{CAR}(-1,10)$ are less significant.

\section{CONCLUSIONS}

The core of modern corporate governance research is the principal-agent issue. In corporate governance, the conflict of the interests between the principle and the agent turns out to be whether the managers can make proper decisions to maximize the shareholders' wealth. It requires the managers to make the most of the recourses, which include the information, to make the best decisions. The market reaction to the previously announced decision is a very valuable information source to managers. Therefore, many scholars have focused their attention on how the managers take full advantage of stock price to make the best investment decisions, with very few concerning the relation between the market reaction and the firms' financing decisions.

Table 10: The Effect Of Family Control On Managers' Learning After Removing The Sino-Foreign Joint Venture

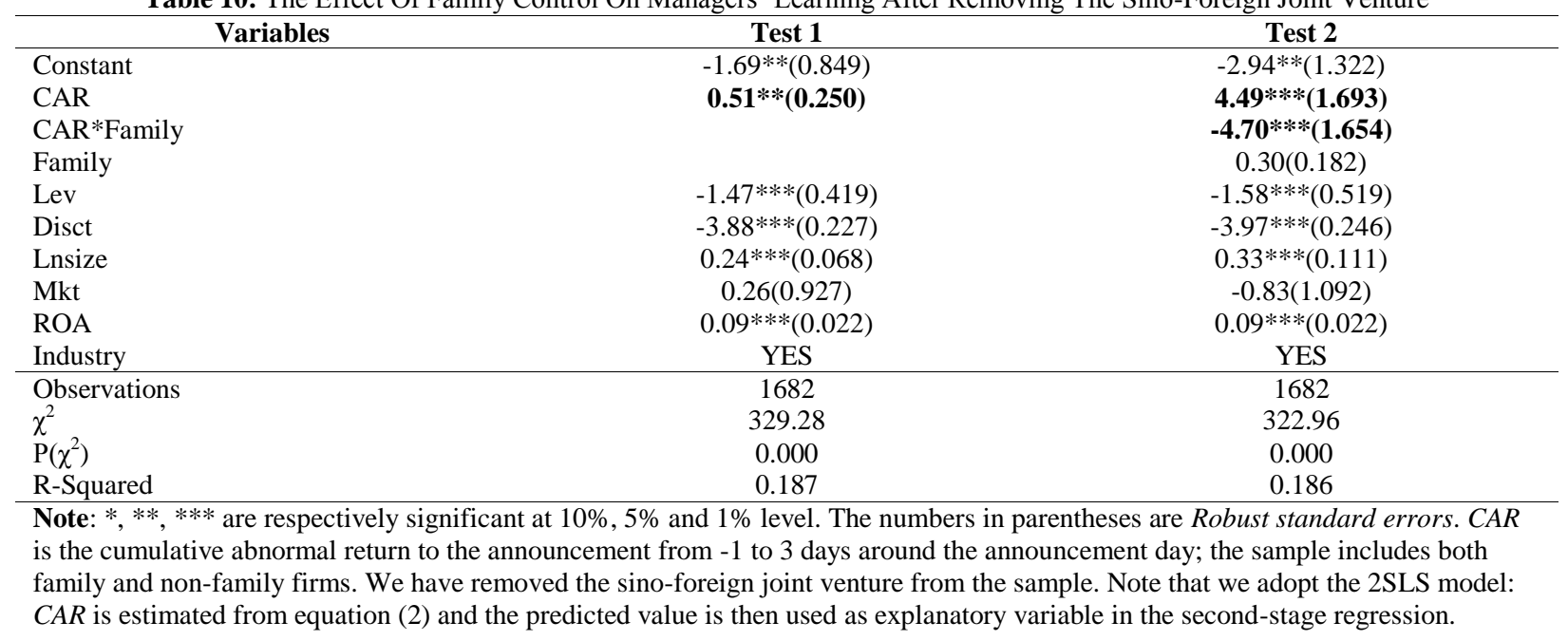


What's more, in the traditional views, the information flow is regarded as one way which is from the firms to the market; in fact, the managers can also utilize the feedback from the market to adjust the announced decisions to maximize firm value. Besides, private placement offers great convenience to small-to-median firms, especially family firms in financing in recent years in China. More and more family firms refinance through private placement. And early work on family firms is mainly concentrated on Western European and Eastern Asian countries, with very few concerning the Chinese family firms. Due to the special characteristics of corporate governance mechanism in family firms, the managers' behavior may be different from that in non-family firms.

This paper contributes to ongoing research by extending the firms' location and the managers' attitude on the market feedback through the study on family firms' private placement. First, unlike the fixed cut-offs of control rights used in previous studies to identify a family firm, we provide evidence on the nature of controlling shareholders directly to judge whether a firm is family-controlled. Second, we show what effect of different separation level of family's control rights and ownership is associated with managers' learning. Finally, we provide evidence on how the corporate governance affects managers' learning in family firms.

For a sample of Chinese family firms who announced private placement, we find that average ownership by the family is $25.64 \%$. And the involvement of family control can make the managers less likely to learn from the market on the whole. However, managers in family-controlled firms with low levels of ownership are more likely to ignore market feedback than those in family-controlled firms with high levels of ownership. We find no relation between the independent directors and the managers' learning. And when the family control is high enough to influence the firm's decision-making process but the ownership is very low, the family can tunnel the minority shareholders; when the family has both high control and high ownership of the firm, they act as steward more than agents and will prop the firm. Thus, the managers in family firms are not absolute agents or stewards but some extent of combination of both. It depends on their shareholdings of the firm. And the agency problem exists mainly between the family and the minority shareholders.

Several implications are included in our work. First, the families' tunneling results from information asymmetry. The insufficient disclosure of the private placement information is bad for the market to evaluate firm value, causing stock price to fall down, which damages the shareholders' interests. Hence, the management department of China securities issuance should strengthen the management of the information disclosure of private placement and improve the transparency of the related information, especially for family firms. Second, the responsibility of independent directors should be improved to strengthen the supervision on the managers and family members to prevent them from seeking personal interests through private placement or other ways. Finally, in the presence of family control, increasing the ownership level are effect ways to mitigate the conflict between majority and minority shareholders caused by the separation of ownership and control rights.

\section{ACKNOWLEDGEMENTS}

This study is funded by the National Science Foundation of China [no. 71202043] and Social Sciences Research Project of Ministry of Education [no. 14XJC790001].

\section{AUTHOR INFORMATION}

Dr. Wanli Li is a professor of accounting in the School of Management at Xi' an Jiaotong University and School of Accounting at Shanghai University of International Business and Economics. Her main research interests include accounting restatements, earnings management, corporate governance and political connections. Wanli Li, Mailing address: No.28, Xianning West Road, Xi’an, Shaanxi, 710049, P.R. China. E-mail: 1wlxjtu@126.com

Weiwei Gao is a Ph.D. candidate of accounting in the School of Management at Xi'an Jiaotong University. Her main research interests include corporate governance and corporate finance. Weiwei Gao, School of Management, Xi'an Jiaotong University, Xi'an, China. Mailing address: Mailbox 1851, No.28, Xianning West Road, Xi'an, Shaanxi, 710049, P.R. China. E-mail: corin0913@gmail.com (Corresponding author). Tel: +86 13474027988 
Wei Sun is a professor of Investment and Finance in the School of Management in Xi'an Jiaotong University. He received his PH.D in manage science from Xi'an Jiaotong University in 2002. His research interests include investment, finance and merger and acquisition, his email address is sunwei@ mail.xjtu.edu.cn.

\section{REFERENCES}

Aktas, N., de Bodt, E., \& Roll, R. (2009). Learning, hubris and corporate serial acquisitions. Journal of Corporate Finance, 15, 543-561.

Aktas, N., de Bodt, E., \& Roll, R. (2011). Serial acquirer bidding: An empirical test of the learning hypothesis. Journal of Corporate Finance, 17, 18-32.

Ali, A., Chen, T., \& Radhakrishnan, S. (2007). Corporate disclosures by family firms. Journal of Accounting and Economics, 44, 238-286.

Anderson, R., Duru, A., \& Reeb, D. (2009). Founders, heirs, and corporate opacity in the United States. Journal of Financial Economics, 92, 205-222.

Anderson, R. \& Reeb, D. (2003). Founding-family ownership and firm performance: Evidence from the S\&P 500. Journal of Finance, 58, 1301-1327.

Anderson, R. \& Reeb, D. (2004). Board composition: balancing family influence in S\&P 500 firms. Administrative Science Quarterly, 49, 209-237.

Anderson, R., Reeb, D., \& Zhao, W. (2012). Family-controlled firms and informed trading: Evidence from short sales. Journal of Finance, 67, 351-385.

Andres, C. (2008). Large shareholders and firm performance: an empirical examination of founding-family ownership. Journal of Corporate Finance, 14, 431-445.

Barclay, M., Holderness, C., \& Sheehan, D. (2007). Private Placements and Managerial Entrenchment. Journal of Corporate Finance, 13, 461-484.

Berger, A., \& Udell, G. (2002). Small business credit availability and relationship lending: The importance of bank organizational structure. The Economic Journal, 112, 32-53.

Bertrand, M., Mehta, P., \& Mullainathan, S. (2002). Ferreting out tunneling: An application to Indian business groups. The Quarterly Journal of Economics, 117, 121-148.

Bertrand, M., \& Schoar, A. (2006). The role of family in family firms. Journal of Economic Perspectives, 20, 73-96.

Blanchard, O., Rhee, C., \& Summers, L. (1993). The stock market, profit and investment. The Quarterly Journal of Economics, 108, 115-136.

Burkart, M., Panunzi, F., \& Shleifer, A. (2003). Family firms. The Journal of Finance, 58, 2167-2202.

Chakraborty, A., \& Hu, C. (2006). Lending relationships in line-of-credit and nonline-of-credit loans: Evidence from collateral use in small business. Journal of Financial Intermediation, 15, 86-107.

Cheng, Q. (2014). Family firm research- A review. China Journal of Accounting Research, 7, 149-163.

Claessens, S., Djankov, S., Fan, J., \& Lang, L. (2002). Disentangling the incentive and entrenchment effects of large shareholdings. The Journal of Finance, 57, 2741-2771.

Claessens, S., Djankov, S., \& Lang, L. (2000). The separation of ownership and control in East Asian corporations. Journal of Financial Economics, 58, 81-112.

Dye, R. \& Sridhar, S. (2002). Resource allocation effects of price reactions to disclosures. Contemporary Accounting Research, 19, 385-410.

Faccio, M., \& Lang, L. (2002). The ultimate ownership of Western European corporations. Journal of Financial Economics, 65, 365-395.

Faccio, M., Lang, L., \& Young, L. (2001). Dividends and expropriation. American Economic Review, 91, 54-78.

Hertzel, M., Lemmon, M., Linck, J., \& Rees, L. (2002). Long-run performance following private placements of equity. The Journal of Finance, 57, 2595-2617.

Jensen, M.C., \& Meckling, W.H. (1976). Theory of the firm: Managerial behavior, agency costs and ownership structure. Journal of Financial Economics, 3, 305-360.

Jennings, R.H., \& Mazzeo, M.A. (1991). Stock price movements around acquisition announcements and management's response. Journal of Business, 64, 139-163.

Kau, J., Linck, J., \& Rubin, P. (2008). Do managers listen to the market? Journal of Corporate Finance, 14, 347362.

La Porta, R., Lopez-de-Silanes, F., \& Shleifer, A. (1999). Corporate ownership around the world. The Journal of Finance, 54, 471-517. 
La Porta, R., Lopez-de-Silanes, F., Shleifer, A., \& Vishny. R. (2000). Investor protection and corporate governance. Journal of Financial Economics, 58, 3-27.

Luo, Y. (2005). Do insiders learn from outsiders? Evidence from mergers and acquisitions. The Journal of Finance, 60, 1951-1982.

Maury, B. (2006). Family ownership and firm performance: Empirical evidence from Western European corporations. Journal of Corporate Finance, 12, 321-341.

McGuire, J., Dow, S., \& Ibrahim, B. (2012). All in the family? Social performance and corporate governance in the family firm. Journal of Business Research, 65, 1643-1650.

Morck, R., \& Yeung, B. (2003). Agency problems in large family business groups. Entrepreneurship Theory and Practice, 27, 367-382.

Setia-Atmaja, L., Haman, J., \& Tanewski, G. (2011). The role of board independence in mitigating agency problem II in Australian family firms. The British Accounting Review, 43, 230-246.

Shleifer, A., \& Vishny, R. (1997). A survey of corporate governance. The Journal of Finance, 52, 737-783.

Tan, R., Chng, P., \& Tong, Y. (2002). Private placements and rights issues in Singapore. Pacific-Basin Finance Journal, 10, 29-54.

Uchida, H., Udell, G., \& Yamori, N. (2012). Loan officers and relationship lending to SMEs. Journal of Financial Intermediation, 21, 97-122.

Villalonga, B. \& Amit, R. (2006). How do family ownership, control and management affect firm value? Journal of Financial Economics, 80, 385-417.

Wang, D. (2006). Founding family ownership and earnings quality. Journal of Accounting Research, 44, 619-656.

Woidtke, T. (2002). Agents watching agents? Evidence from pension fund ownership and firm value. Journal of Financial Economics, 63, 99-131.

Wu, Y. (2004). The choice of equity-selling mechanisms. Journal of Financial Economics, 74, 93-119.

Wu, Z., Chua, J, \& Chrisman, J. (2007). Effects of family ownership and management on small business equity financing. Journal of Business Venturing, 22, 875-895.

Yeh, Y., Lee, T., \& Woidtke, T. (2001). Family control and corporate governance: Evidence from Taiwan. International Review of Finance, 2, 21-48. 